\title{
System of indicators for planning and evaluating production capacity of a construction and installation organization
}

\author{
Ivan Abramov*, and Anastasia Martyanova \\ Moscow State University of Civil Engineering, 129377, Moscow, Russia
}

\begin{abstract}
To assess the production capacity of a construction and installation organization, the actual volume of work performed for a certain period and planned indicators for the use of certain resources are used. Since the state of production facilities depends not only on the production program, but also on the current state of labor resources, the actual task is to choose the most effective criteria for planning and evaluating the production capacity of a construction and installation organization. In formulating the criteria, the author was guided by the theory, allowing to establish the relationship between the production capacity of buildingassembling organizations and production program and capabilities assessment and planning of production capacity for the coefficients of their extensive and intensive use. The study made it possible to form a system of indicators for planning and evaluating the production capacity of a construction and installation organization. The purpose of forming a system of indicators for planning and evaluating production capacities is to take into account in the calculations not only the actual and planned volumes of construction and installation works, but also indicators that reflect the current state of labor resources. The study revealed that through the formation of a system of evaluation indicators, taking into account the impact on production capacity of quantitative and qualitative factors expressed in the structure of labor resources, their qualifications on the one hand, as well as the rhythm and load of the construction and installation organization on the other hand.
\end{abstract}

\section{Introduction}

An integral part of the construction and installation organization is the production facilities that integrating various types of resources. For planning and evaluating production capacities, various evaluation indicators are used to establish the relationship between the actual volume of construction and installation work performed and production capacity, as well as to assess the impact on production capacity of the established work schedules of personnel and equipment.

\footnotetext{
*Corresponding author: ivan2193@yandex.ru
} 
One of the sources of increasing the efficiency and reliability of the construction and installation organization is the correct choice of indicators for planning and evaluating production capacity (potential). This assumption is valid, since the maximum amount of construction and installation work performed by the enterprise on its own per unit of time depends on the size of the production capacity.

However, these indicators do not take into account the scope of activity of the construction and installation organization, the selected type of organizational structure and planned indicators. In this article, it is recommended to plan and evaluate production capacities on the basis of private indicators. For it is necessary to form a system of indicators estimation the relationship of production with capacity number of employees and their production, the rhythm of construction works, the structure of professional groups of workers and scope of planned and completed construction works.

In determining production capacity, followed by preparation of the production program for the implementation of the capital construction object there is a need to address some fundamental management issues to increase productivity, accounting, balance of labor and the need for supply of construction material and technical resources to achieve higher performance efficiency $[1,3]$.

The problem is that as the production capacity of the construction and installation organization increases or the maximum possible amount of work per unit of time, there is a decrease in the increase in resource utilization. Along with the growth of capacity, the costs associated with the operation and maintenance of additional construction units of equipment, as well as other elements of production assets, increase [6].

One of the main tasks is to take into account the impact on the production capacity of the construction and installation organization of time, quality and economic indicators, among which the work notes:

- Evaluative indicators for calculating production capacity by the number of employees and their output.

- Evaluative indicators for calculating production capacity based on the rhythm of construction and installation works.

- Evaluative indicators for calculating production capacity according to the structure of professional groups of workers.

- Evaluative indicators of calculation of production capacity by the volume of construction and installation works performed.

\section{Materials and Methods}

The calculation of planned production capacity takes into account the required amount of resources, the difference between the actual resources consumed and the planned ones. Taking this into account will ensure a balanced production program.

There is a pronounced relationship between the production capacity and the production program. The production program allows you to distribute production capacity in the context of time. The method of planning the production capacity of a construction and installation organization is aimed at eliminating imbalances in production plans.

To calculate the production capacity, the main indicators are [7]:

- the actual availability of resources on which the production potential of the construction and installation organization depends $\left(\mathrm{R}_{\mathrm{a}}\right)$;

- the planned maximum possible annual fund of the time of use of a certain resource $\left(\mathrm{T}_{\mathrm{p}}\right)$;

- planned maximum possible performance of resource usage per unit of time $\left(\mathrm{P}_{\mathrm{p}}\right)$. 
Production capacity (C) is defined as the sum of the listed indicators by the following formula:

$$
C=R_{a}+T_{p}+P_{p}
$$

Directly related to the production capacity is the actual volume of work performed (Va) by the construction and installation organization for a certain period, which is determined by the formula:

$$
V_{a}=R_{a}+T_{a}+P_{a}
$$

where $T_{a}$ - the actual maximum possible annual fund of the time of use of a certain resource;

$P_{a}$ - the actual maximum possible performance of resource usage per unit of time.

There is a mathematical relationship between the actual volume of work performed and the production capacity, which can be represented using the formula:

$$
C=\frac{V_{a}}{T_{a} / T_{p}{ }^{*}{ }^{P} / P_{p}} .
$$

The mathematical relationship between the production capacity and the actual volume performed can be presented in the following form based on the methodology for evaluating the efficiency of production capacity by the coefficients of extensive $\left(K_{e i}\right)$ and intensive (Kii) resource use [7]:

$$
C=\frac{V_{a}}{K_{e i} * K_{i i}}
$$

The production capacity of a construction and installation organization is affected by critical and leading resources. Critical resources limit the ability to expand the production program, and leading resources are used to perform the main volume of construction and installation work.

The most important resources in the construction and installation organization are fixed assets in terms of volume, composition and structure of which assess the current state of production facilities. An important resource for performing construction and installation works is the composition and structure of labor resources [8].

In general, indicators for assessing the production potential are divided into two main groups:

- indicators for determining the production potential of the construction and installation organization, including the cost of fixed assets, the number of personnel;

- indicators for assessing the possibility of expanding production areas, such as the level of material intensity of construction, the share of the active part of production assets in the overall structure.

- Production facilities can be classified according to the following criteria [2]:

- passport (theoretical) production capacity, which is estimated using the volume of operations performed in working conditions with minimal influence of negative factors;

- practical production capacity, reflecting the maximum level of production achieved by reducing the loss of working time to perform unforeseen work, such as equipment repairs;

- normal production capacity corresponding to the average level, which is sufficient to meet the demand for the services provided for a certain period of time; 
- planned production capacity corresponding to the annual rate of production capacity.

When calculating production capacities, the following requirements must be taken into account, namely:

- data on all production equipment with the exception of backup equipment;

- the maximum possible fund of working time of the equipment at the shift mode established in the construction and installation organization;

- modern ways of organizing construction production;

- technical standards for the performance of equipment, the work performed and the complexity of the work performed.

To determine the actual production capacity of a construction and installation organization, it is recommended to use indicators of the use of machine $(\mathrm{Km})$ and labor (Kl) resources, as well as the volume of work performed with the help of mechanization tools $(\mathrm{m})[4]$ :

$$
C_{a}=V_{a} \cdot\left(\frac{m}{K_{m}}+\frac{1-m}{K_{l}}\right)
$$

The disadvantage of using these indicators is that there is no information on time losses to calculate the utilization rate of machine resources, and the specifics of the construction and installation organization performed and the type of management structure are not taken into account.

Thus, the production capacity of many construction and installation organizations may belong to organizations that perform subcontracting work or be used under a lease agreement, and such organizations do not keep records of construction machinery and equipment.

\section{Results}

The study made it possible to form a system of indicators for planning and evaluating the production capacity of a construction and installation organization.

To solve the problems of planning and evaluating production capacities, it is necessary to use methods that allow determining the production capacity by the number of employees and their development, the rhythm of construction and installation works, the structure of professional groups of workers, the volume of construction and installation works performed.

Estimated indicators for calculating production capacity by the number of employees and their development are shown in Table 1.

Table 1. Estimated indicators for calculating production capacity based on the number of employees and their development

\begin{tabular}{cl}
\hline & \multicolumn{1}{c}{ Name of key indicators } \\
\hline 1 & Average annual production capacity in the planned year $(C)$ \\
\hline 2 & $\begin{array}{l}\text { Actual number of employees involved in construction and installation works and } \\
\text { auxiliary production }(H)\end{array}$ \\
\hline 3 & The coefficient of labour force $\left(K_{h}\right)$ \\
\hline 4 & $\begin{array}{l}\text { The coefficient of production output by one employee engaged in construction and } \\
\text { installation works }\left(K_{p e}\right)\end{array}$ \\
\hline
\end{tabular}

The estimates given in Table 1 are summarized in formula 6:

$$
C=H \cdot P_{n} \cdot K_{h} \cdot K_{p e}
$$


Thus, to evaluative the average annual production capacity in the planned year, it is necessary to consider the actual number of employees involved in the execution of construction work, the ratio of involved labor, as well as a factor of production by one worker of construction works.

Estimated indicators for calculating production capacity based on the rhythm of construction and installation work are shown in Table 2.

Table 2. Estimated indicators for calculating production capacity based on the rhythm of construction and installation work

\begin{tabular}{cl}
\hline & Name of key indicators \\
\hline 1 & Production capacity of a construction and installation organization for a certain month $\left(C_{i}\right)$ \\
\hline 2 & Average monthly production capacity $\left(C_{a v}\right)$ \\
\hline 3 & The coefficient of labour force $\left(K_{h}\right)$ \\
\hline 4 & Maximum monthly production capacity $\left(C_{\max }\right)$ \\
\hline 5 & Average maximum monthly production capacity $\left(C_{\text {av.max }}\right)$ \\
\hline
\end{tabular}

The estimates given in Table 2 are summarized in formula 7 and 8 :

$$
\begin{gathered}
C_{a v}=\left(\frac{C_{1}+C_{2}+C_{3}+C_{4}}{4}\right), \\
C_{\text {max }}=C_{a v \text { max }} \cdot 12 \cdot K_{h .}
\end{gathered}
$$

It should be noted that the production capacity of a construction organization for a certain month depends on the specifics of the work performed, their seasonal nature and, depending on the period, the indicators can vary significantly, which is a distinctive feature of the construction industry. The coefficient of employed labor resources depends not only on the degree of involvement of own workers, but also it is necessary to take into account the contractors and subcontractors involved in the implementation of construction and installation works.

The more labor resources are involved in construction and installation works, the higher the ratio of labor resources involved and the more efficient the use of production capacities [5].

Evaluative indicators for calculating production capacity by the structure of professional groups of workers are shown in Table 3.

Table 3. Estimated indicators for calculating production capacity by the structure of professional groups of workers

Name of key indicators

\begin{tabular}{cl}
\hline 1 & Production capacity for i-group of works $\left(C_{i}\right)$ \\
\hline 2 & Total number of employees in the professional group $\left(H_{t}\right)$ \\
\hline 3 & Planned number of working days per year per worker $(D)$ \\
\hline 4 & Labor intensity per unit of work $\left(L_{u}\right)$ \\
\hline 5 & Estimated cost of a unit of measurement of work $\left(E_{c}\right)$ \\
\hline 6 & $\begin{array}{l}\text { The coefficient that takes into account the over fulfill of the professional group of the } \\
\text { work rate }\left(K_{f}\right)\end{array}$ \\
\hline
\end{tabular}

The estimates given in Table 3 are summarized in formula 9 and 10:

$$
\begin{gathered}
C=C_{1}+C_{2}+C_{n}, \\
C_{i}=\frac{H_{t} \cdot D}{L_{u}} \cdot E_{c} \cdot K_{f}
\end{gathered}
$$


The initial data for calculating the production capacity of a construction and installation organization that has its own machines and mechanisms are [9]:

- volumes of construction and installation works performed in the base period;

- the volume of earthworks performed in the base period;

- estimated cost per unit of work volume;

- the number of machine hours actually worked in the base period;

- the planned estimated cost of the car-hour.

- number of employees involved in construction and installation works;

- the planned number of employees involved in construction and installation works;

- planned production capacity of the construction equipment fleet.

Evaluative indicators for calculating production capacity by the volume of construction and installation works performed using own funds are shown in Table 4.

Table 4. Estimated indicators for calculating production capacity by the volume of completed construction and installation works

\begin{tabular}{|c|c|c|}
\hline & Criterion & Calculation formula \\
\hline 1 & $\begin{array}{l}\text { The cost of work actually performed in the base year by } \\
\text { construction machines, the volume of which is accounted for by } \\
\text { natural indicators }(E n) \\
\text { The volume of work performed in the base year by the i-th group } \\
\text { of construction machines, physical units. the scope of work }\left(V_{a}\right) \\
\text { The average estimated cost of a unit of physical volume of work } \\
\text { performed by the i-th group of machines }\left(E_{i}\right)\end{array}$ & $E_{n}=\sum_{i=1}^{n} \frac{V_{a} \cdot E_{i}}{1000}$ \\
\hline 2 & $\begin{array}{l}\text { The cost of work actually performed in the base year by } \\
\text { construction machines }\left(E_{m}\right) \\
\text { The number of machine hours actually worked by the i-group of } \\
\text { construction machines in the base year }\left(L_{m h i}\right) \\
\text { Planned-estimated cost of a machine-hour of operation of } \\
\text { construction machines by i-group in the base year }\left(E_{p e i}\right)\end{array}$ & $E_{m}=\frac{L_{m h i} \cdot E_{p e i}}{1000}$ \\
\hline 3 & $\begin{array}{l}\text { Labor resources utilization rate in the base year }\left(K_{h}\right) \\
\text { Research period }\left(T_{r}\right) \\
\text { The coefficient of performance of the plan }\left(K_{p p}\right)\end{array}$ & $K_{h}=\frac{T_{r} \cdot\left(1-K_{p p}\right)}{T_{r}+P}$ \\
\hline 4 & $\begin{array}{l}\text { The number of machine days actually worked by construction } \\
\text { vehicles in the base year }\left(L_{m d i}\right) \\
\text { The number of whole-day losses in the operation of machines in } \\
\text { the base year }\left(N_{l i}\right) \\
\text { The duration of the work shift }\left(T_{s h}\right) \\
\text { The shift index of work construction machines mounted on the } \\
\text { base year }\left(K_{s h}\right)\end{array}$ & $\begin{array}{l}K_{h i} \\
=\frac{L_{m h i}}{\left(L_{m d i}+N_{l i}\right) \cdot T_{s h}}\end{array}$ \\
\hline 5 & $\begin{array}{l}\text { Utilization factor for the entire range of machines }\left(K_{u}\right) \\
\text { Estimated cost of machine hours worked by the i-group of } \\
\text { construction machines }\left(E_{i}\right)\end{array}$ & $K_{u}=\sum_{i=1}^{n} \frac{K_{u i} \cdot E_{i}}{\sum_{i=1}^{n} E_{i}}$ \\
\hline 6 & $\begin{array}{l}\text { Average annual production capacity }\left(C_{b}\right) \\
\text { Estimated cost of construction and installation works actually } \\
\text { performed by the organization's own forces in the base year }\left(E_{a}\right)\end{array}$ & $\begin{array}{l}C_{b} \\
=\frac{E_{a}-E_{n}-E_{m}}{K_{h}} \\
+\frac{E_{n}+E_{m}}{K_{h}}\end{array}$ \\
\hline
\end{tabular}

$7 \quad$ Production area at the beginning of the planned period $\left(S_{p p}\right)$

The ratio of the capacity of the fleet of leading construction machines at the beginning of the planned year to their average annual capacity in the base year $\left(C_{r}\right)$

The growth factor production leading construction machinery $\left(K_{l m}\right)$

Indicator of the leading type of machines that determines the 
performance of the main volume of mechanized work of the organizational and production system $\left(I_{m}\right)$

8 Average annual production area in the planned year $\left(C_{p a}\right) \quad C_{p a}=S_{p p}$.

The planned annual capacity of the machinery of organization for the leading mind machines, units of measurement of power $\left(R_{p a}\right)$

$$
\begin{gathered}
\frac{\left(100-I_{m}\right) \cdot H_{p a}}{H_{p p}}+ \\
+\frac{I_{m} \cdot R_{p a}}{R_{p p}}
\end{gathered}
$$

\section{Discussion}

As a result of the calculations made for each of the above methods, different values are obtained from the planned average annual production capacity. The obtained data can be presented in the form of a Boolean expression $P C_{4}<P C_{2}<P C_{1}<P C_{3}$. In this case:

- planned production capacity $\left(P C_{l}\right)$ is calculated based on the number of employees and their output;

- planned production capacity $\left(P C_{2}\right)$ is calculated based on the rhythm of work performance;

- planned production capacity $\left(P C_{3}\right)$ is calculated on the basis of professional groups;

- planned production capacity $\left(P C_{4}\right)$ is calculated on the basis of the presence and power of the leading machines and mechanisms.

Assessment of the production load allows you to choose directions to increase the immunity of the existing production capacities of the construction and installation organization to various factors, reduce the implementation time of construction projects, introduce innovations at all stages of the life cycle of the construction project, and reduce risks.

\section{Conclusion}

The study of methods for planning and evaluating production capacities allowed us to establish the relationship between production capacity and the number of employees and their output, the rhythm of construction and installation work, the structure of professional groups of workers, the volume of construction and installation work performed.

The necessary results were achieved through the formation of a system of evaluation indicators, taking into account the impact on production capacity of quantitative and qualitative factors expressed in the structure of labor resources, their qualifications on the one hand, as well as the rhythm and load of the construction and installation organization on the other hand.

It was found that estimates of the average annual production capacity in the planned year should take into account the actual number of employees involved in construction and installation work, the ratio of labor resources involved, as well as the coefficient of output by one employee involved in construction and installation work.

To calculate the production capacity based on the structure of professional working groups, it is necessary to take into account:

- production capacity for each group of construction and installation works performed;

- total number of employees in the professional group;

- planned number of working days per year per worker;

- labor intensity per unit of work measurement;

- estimated cost of the unit of measurement of work; 
- a coefficient that takes into account the over-fulfillment of the work rate by the professional group.

The calculation of production capacity based on the volume of construction and installation works performed makes it possible to take into account the cost of actually performed works, the labor resource utilization rate in the base year, the actual days worked, the shift rate of work and other indicators.

Consideration of these quantitative and qualitative indicators contributes to the growth of productivity and balance in the planning and evaluation of the production program and is a prerequisite for building production of the necessary logistical resources to increase production capacities, construction and installation organizations.

\section{References}

1. E.V. Atamas, Prospects for the development of a comfortable urban environment in the concept of sustainable development, Economics of sustainable development 4, 25-29 (2019)

2. H.M. Gumba, Planning at the enterprise in the construction industry: textbook and workshop (Yurayt, Moscow, 2020)

3. A.N. Dmitriev, Development of the regulatory framework for the implementation of the national project "Housing and Urban environment".

4. E.M. Zeiger, B.N. Gishakov, Methodological recommendations for calculating the production capacity of road construction organizations (Soyuzdornii, Moscow, 1981)

5. Yu.A. Makarichev, Methods of experiment planning and data processing: textbook. manual (ASI of Samara State Technical University, Samara, 2016)

6. D.S. Saraeva, Risk assessment in uncertainty arising in construction production (ZAO Universitetskaya kniga, 2019) p. 184-186.

7. A.V. Pilyugina, A.V. Mishchenko, Models for assessing the production capacity of an enterprise, Bulletin of the Bauman Moscow State Technical University. Series "Mechanical Engineering" 3, 102-121 (2017)

8. Hamed Shoja, Mohsen Haidar, The role of sustainable urban development and sustainable urban governance in architecture, European Online Journal of Natural and Social Sciences 3, 65-67 (2015)

9. Hui-Ting Tang, Yuh-Ming Lee, The Making of Sustainable Urban Development: A Synthesis Framework (2010)

10. A.A. Lapidus, I.L. Abramov, Systemic integrated approach to evaluating the resource potential of a construction company as a bidder, IOP Conference Series: Materials Science and Engineering 603(5), 052079 (2019)

11. I.L. Abramov, Systemic integrated and dynamic approach as a basis to ensure sustinable operation of a construction company, IOP Conference Series: Materials Science and Engineering 463(3), 032038 (2018) 